\title{
Applying Response Surface Methodology to Optimize the Treatment of Swine Slaughterhouse Wastewater by Electrocoagulation
}

\author{
Ha Manh Bui* \\ Department of Environmental Sciences, Saigon University, Ho Chi Minh City, Vietnam
}

Received: 29 July 2017

Accepted: 9 October 2017

\begin{abstract}
The effects of electrocoagulation on COD removal of Nam Phong swine slaughterhouse wastewater (Binh Thanh District, Ho Chi Minh City, Vietnam) were investigated in this paper. For this purpose, response surface methodology (RSM) was employed to investigate the effects of three operating conditions on COD removal by electrocoagulation (EC) with iron electrodes. A central composite design (CCD) was used to optimize the EC process and to evaluate the individual and interaction effects of current density, electrolysis time, and initial $\mathrm{pH}$. The results, based on statistical analysis, showed that the quadratic models for COD removal efficiency were significant at very low probability value $(<0.0001)$ and high coefficient of determination $\left(\mathrm{R}^{2}=0.9754\right)$. Optimal conditions for COD removal were established at $130 \mathrm{~A} / \mathrm{m}^{2}$ current density, 9.5 min electrolysis time, and initial $\mathrm{pH} 8.5$, in which a removal of $97.3 \%$ was achieved. Operating costs and sludge production at the optimum operating conditions were also calculated for the treatment process.
\end{abstract}

Keywords: electrocoagulation, optimization, swine slaughterhouse wastewater, surface response method

\section{Introduction}

With rapid socio-economic development in Vietnam, many slaughterhouses have been established to meet the meat consumption demand of people [1]. However, a large amount of slaughterhouse wastewater is discharged into the environment annually. Most of the wastewater includes blood, fat, and fur, as well as detergents, preservatives, and pathogenic microbes, etc., that contain large amounts of biochemical oxygen demand $\left(\mathrm{BOD}_{5}\right)$ or chemical oxygen demand (COD) values [2].

*e-mail: manhhakg@yahoo.com.vn,manhhakg@sgu.edu.vn
Therefore, it is necessary to treat the wastewater to some degree before disposal.

Due to the high organic content in characteristic wastewater, most $\mathrm{BOD}_{5}$ and some $\mathrm{COD}$ in the swine slaughterhouse process were normally eliminated by biological treatment such as upflow anaerobic sludge blanket reactor [3], upflow anaerobic filter reactor [4], anaerobic fixed-film reactor [5], etc. However, some research [6] has indicated that the biological process required both a long treatment time for acclimation and huge space for setting up a biological unit. Removal efficiency also greatly depends on the types of organisms in the biological systems. Moreover, in some cases, the organic values (COD or BOD) after 
the biological process do not meet the current water quality standards [1]. Some oxidation processes such as ozonation [7-8], UV radiation [9], photo-degradation [10], etc., have been reported to be not completely effective. Hence, the approach for the rapid and effective removal of contaminants from swine slaughterhouse wastewater is necessary to be further developed.

Recently, a number of investigations have reported that the application of electrocoagulation (a kind of physical-chemical method) had been successful in removing pollutants from different kinds of wastewater, including from hospitals [11], dairy [12], textile [13-14], pesticide [15], herbicide [16], etc. In the electrocoagulation process, a direct electrical current is used to dissolve a metal electrode (mostly iron and aluminium) forming a range of coagulant species and metal hydroxides in that precipitation and adsorption efficiencies are greater than pre-precipitated hydroxides of conventional coagulant like the coagulation process [17]. As compared with mentioned methods, electrocoagulation have many advantages such as low investment cost, low space requirement, the absence or lack of additional chemicals, less retention time, less sludge production, simple equipment, and easy operation $[12,15-16]$. Hence, the application of EC to alleviate the contamination of swine slaughterhouse wastewater offers the promise of an effective process.

The objective of this study was to investigate the pollutant removal capacity of the electrocoagulation process with iron electrodes on Vietnamese swine slaughterhouse wastewater by monitoring the decrease in COD. Response surface methodology (RSM) was used to experiment design, to analyze the effect of three variables (current density, electrolysis time, and initial $\mathrm{pH}$ ), and determine optimum conditions. Sludge production and operational costs were also examined.

\section{Experimental}

\section{Reagents and Apparatus}

Raw swine slaughterhouse wastewater was obtained from Nam Phong Food Processing Enterprise (Ho Chi Minh City, Vietnam). The wastewater samples were kept in polyethylene containers and cooled to room temperature before being preserved at $5^{\circ} \mathrm{C}$ to reduce biodegradation due to biological activity. $\mathrm{pH}$, conductivity, total suspended solids, color, and COD of the raw wastewater were $6.53 \pm 0.15$, $5.78 \pm 0.15 \mathrm{mS} / \mathrm{cm}, 176 \pm 23 \mathrm{mg} / \mathrm{L}, 1,363 \pm 20 \mathrm{Pt}-\mathrm{Co}$, and $4,150 \pm 30 \mathrm{mg} / \mathrm{L}$, respectively.

The experimental set up and use for the electrocoagulation (EC) study could be found in the previous study of Ha [13]. Briefly, a plexiglas reactor with maximum capacity of $5 \mathrm{~L}$ was used for the EC experiment. Four iron electrodes grouped in parallel were placed in the reactor with an active area of
Table 1. Experimental range and levels of independent parameters.

\begin{tabular}{|c|c|c|c|c|c|c|}
\hline \multicolumn{2}{|c|}{} & \multicolumn{5}{|c|}{ Levels } \\
\cline { 3 - 7 } Parameters & -2 & -1 & 0 & +1 & +2 \\
\hline $\begin{array}{c}\text { Electrolysis } \\
\text { time (min) }\end{array}$ & $\mathrm{X}_{1}$ & 4 & 6 & 8 & 10 & 12 \\
\hline $\begin{array}{c}\text { Current density } \\
\left(\mathrm{A} \mathrm{m}^{-2}\right)\end{array}$ & $\mathrm{X}_{2}$ & 65.0 & 86.6 & 108.3 & 130.0 & 151.6 \\
\hline Initial pH & $\mathrm{X}_{3}$ & 4 & 5.5 & 7 & 8.5 & 10 \\
\hline
\end{tabular}

$19.6 \mathrm{~cm}^{2}$. The electrodes were connected to an adjustable DC power supply (220V, 30A) whose polarity automatically switched every 30 seconds to reduce the passivation films on the electrodes.

\section{Procedure and Analysis}

For a typical run, $4 \mathrm{~L}$ of the wastewater were put into the reactor. The initial $\mathrm{pH}$ was adjusted using $\mathrm{H}_{2} \mathrm{SO}_{4}(0.1 \mathrm{M})$ and $\mathrm{NaOH}(0.1 \mathrm{M})$ solutions to reach the desired values, and a constant current density at regular electrolysis time was applied according to the experiment design (Table 1). After $30 \mathrm{~min}$ settling at the end of each run, $50 \mathrm{~mL}$ of the treated samples were withdrawn and then were determined $\mathrm{pH}, \mathrm{COD}$, or other parameters using Standard Methods for the Examination of Water and Wastewater [18]. All the experiments were performed at room temperature of $30 \pm 2^{\circ} \mathrm{C}$.

\section{CCD Response Surface Design}

In the current study, the central composite design (CCD), a standard RSM, was used to find out the individual and interactive effects of process parameters on COD removal capacity of swine slaughterhouse wastewater via Minitab statistical software (version 16.2.0). Electrolysis time $\left(X_{1}\right)$, current density $\left(X_{2}\right)$, and initial $\mathrm{pH}\left(\mathrm{X}_{3}\right)$ were chosen as independent factors, while COD removal efficiency $(\mathrm{Y})$ was selected as response function. The variable range was divided into five levels $(-2,-1,0,+1,+2)$ as shown in Table 1 . The removal efficiencies were fitted to a general function indicating the interaction between dependent and independent variables by the following quadratic (second degree) polynomial equation:

$$
\begin{aligned}
\mathrm{Y} & =\mathrm{b}_{0}+\mathrm{b}_{1} \mathrm{X}_{1}+\mathrm{b}_{2} \mathrm{X}_{2}+\mathrm{b}_{3} \mathrm{X}_{3}+\mathrm{b}_{11} \mathrm{X}_{1}^{2}+\mathrm{b}_{22} \mathrm{X}_{2}^{2} \\
& +\mathrm{b}_{33} \mathrm{X}_{3}^{2}+\mathrm{b}_{12} \mathrm{X}_{1} \mathrm{X}_{2}+\mathrm{b}_{23} \mathrm{X}_{2} \mathrm{X}_{3}+\mathrm{b}_{13} \mathrm{X}_{1} \mathrm{X}_{3}
\end{aligned}
$$

...where $\mathrm{X}_{1}, \mathrm{X}_{2}$, and $\mathrm{X}_{3}$ are the input factors that influence predicted response $Y ; b_{0}$ is the intercept; $b_{1}$, $b_{2}$, and $b_{3}$ are the linear coefficients; $b_{11}, b_{22}$, and $b_{33}$ are the quadratic coefficients; and $b_{12}, b_{23}$, and $b_{13}$ are the interaction coefficients. 
Twenty experiments were conducted, including 6 repeated runs at the central point. Analysis of variance (ANOVA) was used for statistical analysis. The adequacy of the model was evaluated by calculating the determination coefficient $\left(\mathrm{R}^{2}\right)$ in addition to testing it for lack of fit by the $P$ value (probability) with $95 \%$ confidence level. Three-dimensional plots were obtained from the results of the experiments.

\section{Results and Discussion}

Model Fitting and Validation

The significance and adequacy of the predicted model are normally determined by ANOVA. While the F-value describes the variation in the mean of data, the probability F-value (Prob. $>\mathrm{F}$ ) - p value below 0.05 is considered as a significant term. Table 2 presents the ANOVA of regression parameters of the predicted response surface quadratic model and other statistical parameters for COD removal efficiency. The model F-ratio of 44.12 and the $p$ value of 0.000 indicate the employed model is significant. The high $\mathrm{P}$ values 0.113 , 0.510 , and 0.434 for $X_{1} X_{2}, X_{1} X_{3}$, and $X_{2} X_{3}$, respectively, also indicates that all interactions should be eliminated in order to improve the quality of the regression model. Furthermore, the lack of fit F-value of 3.43 is not significantly relative to the pure error to demonstrate that the model successfully predicted the effect of the factors on the treatment process. Therefore, the model for predicting COD removal using the EC process includes a set of coefficients and uncoded factors described as follows:

$$
\begin{gathered}
\mathrm{Y}_{\mathrm{COD}}=28.59 \mathrm{X}_{1}+2.087 \mathrm{X}_{2}+54.936 \mathrm{X}_{3} \\
-1.031 \mathrm{X}_{1}^{2}-0.007 \mathrm{X}_{2}^{2}-3.402 \mathrm{X}_{3}^{2}-395.515
\end{gathered}
$$

The accuracy of an achieved quadratic model could also be checked by the residual plots. If the trend of the residual plot is approximately a straight line, then the residuals are normally distributed or the accuracy of the model is satisfied [19]. Fig. 1a) displays the normal probability plot of the residual for COD removal on the EC process, which is approximately a straight line. The determination coefficient $\left(\mathrm{R}^{2}\right)$ and adjusted determination coefficient $\left(\mathrm{R}_{\text {adj }}{ }^{2}\right)$ for the quadratic model were found to be $97.54 \%$ and $95.33 \%$, respectively. The amount of $\mathrm{R}^{2}$ suggested that less than $2.46 \%$ of the variations in the response variable of COD removal could not be explained by this model. This relationship between the experimental and predicted values could be confirmed by the good agreement described in Fig. 1b) [20].

\section{Effects of Operating Parameters}

The design matrix with experimental and predicted COD removal efficiencies is listed in Table 3.

The best percentage removal efficiency of COD reached $96.2 \%$, which is significantly higher than the $76.5 \%$ COD removal case using the ferrous sulfate combined ferric chloride coagulation process of Mahtab and Tariq [21]. The Response surface plot (Fig. 2) was carried out to check the influence of three operating parameters on COD removal. It could be ascertained from Fig. 2a) that at first the COD removal percentage

\begin{tabular}{|c|c|c|c|c|c|c|}
\hline Source & DF & Seq SS & Adj SS & Adj MS & F- value & $\mathrm{P}$ \\
\hline Model & 9 & $6,124.07$ & $6,124.07$ & 680.45 & 44.12 & 0.000 \\
\hline $\mathrm{X}_{1}$ & 1 & 949.41 & 387.22 & 387.22 & 25.11 & 0.000 \\
\hline $\mathrm{X}_{2}$ & 1 & 799.62 & 234.58 & 234.58 & 15.21 & 0.003 \\
\hline $\mathrm{X}_{3}$ & 1 & $2,628.36$ & 785.87 & 785.87 & 50.96 & 0.000 \\
\hline $\mathrm{X}_{1}{ }^{2}$ & 1 & 427.89 & 427.89 & 427.89 & 27.75 & 0.000 \\
\hline $\mathrm{X}_{2}^{2}$ & 1 & 46.88 & 289.22 & 289.22 & 18.75 & 0.001 \\
\hline $\mathrm{X}_{3}^{2}$ & 1 & $1,207.86$ & $1,473.00$ & $1,473.00$ & 95.51 & 0.000 \\
\hline$X_{1} X_{2}$ & 1 & 46.61 & 46.61 & 46.61 & 3.02 & 0.113 \\
\hline $\mathrm{X}_{1} \mathrm{X}_{3}$ & 1 & 7.20 & 7.20 & 7.20 & 0.47 & 0.510 \\
\hline $\mathrm{X}_{2} \mathrm{X}_{3}$ & 1 & 10.24 & 10.24 & 10.24 & 0.66 & 0.434 \\
\hline Residual error & 10 & 154.22 & 154.22 & 15.42 & & \\
\hline Lack of fit & 5 & 119.43 & 119.43 & 23.89 & 3.43 & 0.101 \\
\hline Pure error & 5 & 34.79 & 34.79 & 6.96 & & \\
\hline Total & 19 & $6,278.29$ & & & & \\
\hline
\end{tabular}

Table 2. Analysis of variance (ANOVA) for COD removal efficiency (\%).

$\mathrm{R}^{2}=0.9754$ and $\mathrm{R}_{\text {adj }}^{2}=0.9533$ 

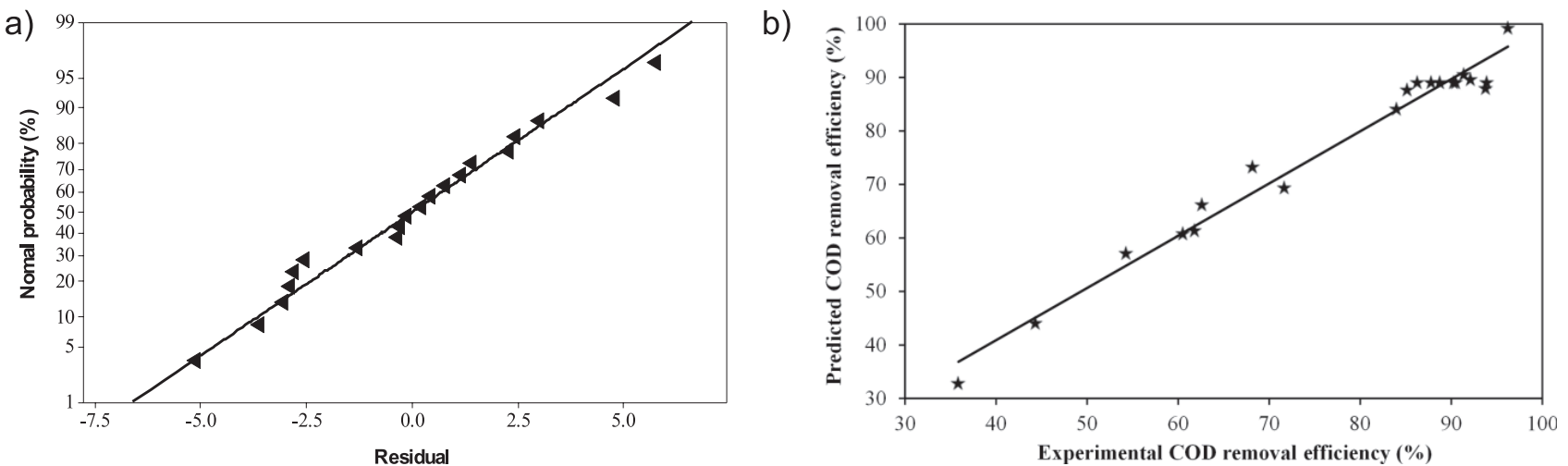

Fig. 1. Diagnostic plots for COD removal efficiencies: a) probability plot and b) actual vs. predicted plot.

increases with increased electrolysis time and current density. However, as the current density or electrolysis time reached "suitable" values, COD removal efficiency was no longer improved. These results should be explained because the iron coagulant was saturated in the solution and could not react efficiently. This observation is in agreement with the state of Abdel and Baraka [15], as they eliminated pesticides from simulated wastewater using electrocoagulation. A similar trend was recorded as changing electrolysis time vs. initial $\mathrm{pH}$ (Fig. 2b), the percentage COD increases with increasing in the initial $\mathrm{pH}$ from acidic condition to slightly alkaline (around 8) for given electrolysis time. Further increases in initial $\mathrm{pH}$ (to 10) at long reaction time did not show any significant improvement in the percentage COD removal, which

Table 3. Central composite design and experimental results.

\begin{tabular}{|c|c|c|c|c|c|}
\hline \multirow{2}{*}{ Run } & \multicolumn{3}{|c|}{ Experimental design } & \multicolumn{2}{|c|}{ COD removal efficiency (\%) } \\
\hline & Electrolysis time $\left(\mathrm{X}_{1}\right)$ & Current density $\left(\mathrm{X}_{2}\right)$ & Initial pH $\left(\mathrm{X}_{3}\right)$ & Experimental & Predicted \\
\hline 1 & -1 & -1 & -1 & 44.34 & 44.12 \\
\hline 2 & +1 & -1 & -1 & 62.63 & 66.25 \\
\hline 3 & -1 & +1 & -1 & 60.53 & 60.82 \\
\hline 4 & +1 & +1 & -1 & 68.17 & 73.30 \\
\hline 5 & -1 & -1 & +1 & 71.67 & 63.39 \\
\hline 6 & +1 & -1 & +1 & 85.17 & 87.72 \\
\hline 7 & -1 & +1 & +1 & 91.39 & 90.62 \\
\hline 8 & +1 & +1 & +1 & 96.23 & 99.30 \\
\hline 9 & -2 & 0 & 0 & 54.29 & 57.20 \\
\hline 10 & +2 & 0 & 0 & 93.78 & 88.02 \\
\hline 11 & 0 & -2 & 0 & 61.82 & 61.41 \\
\hline 12 & 0 & +2 & 0 & 92.12 & 89.68 \\
\hline 13 & 0 & 0 & -2 & 35.85 & 32.86 \\
\hline 14 & 0 & 0 & +2 & 83.99 & 84.13 \\
\hline 15 & 0 & 0 & 0 & 86.29 & 89.11 \\
\hline 16 & 0 & 0 & 0 & 88.74 & 89.11 \\
\hline 17 & 0 & 0 & 0 & 93.91 & 89.11 \\
\hline 18 & 0 & 0 & 0 & 90.27 & 89.11 \\
\hline 19 & 0 & 0 & 0 & 90.51 & 89.11 \\
\hline 20 & 0 & 0 & 0 & 87.80 & 89.11 \\
\hline
\end{tabular}



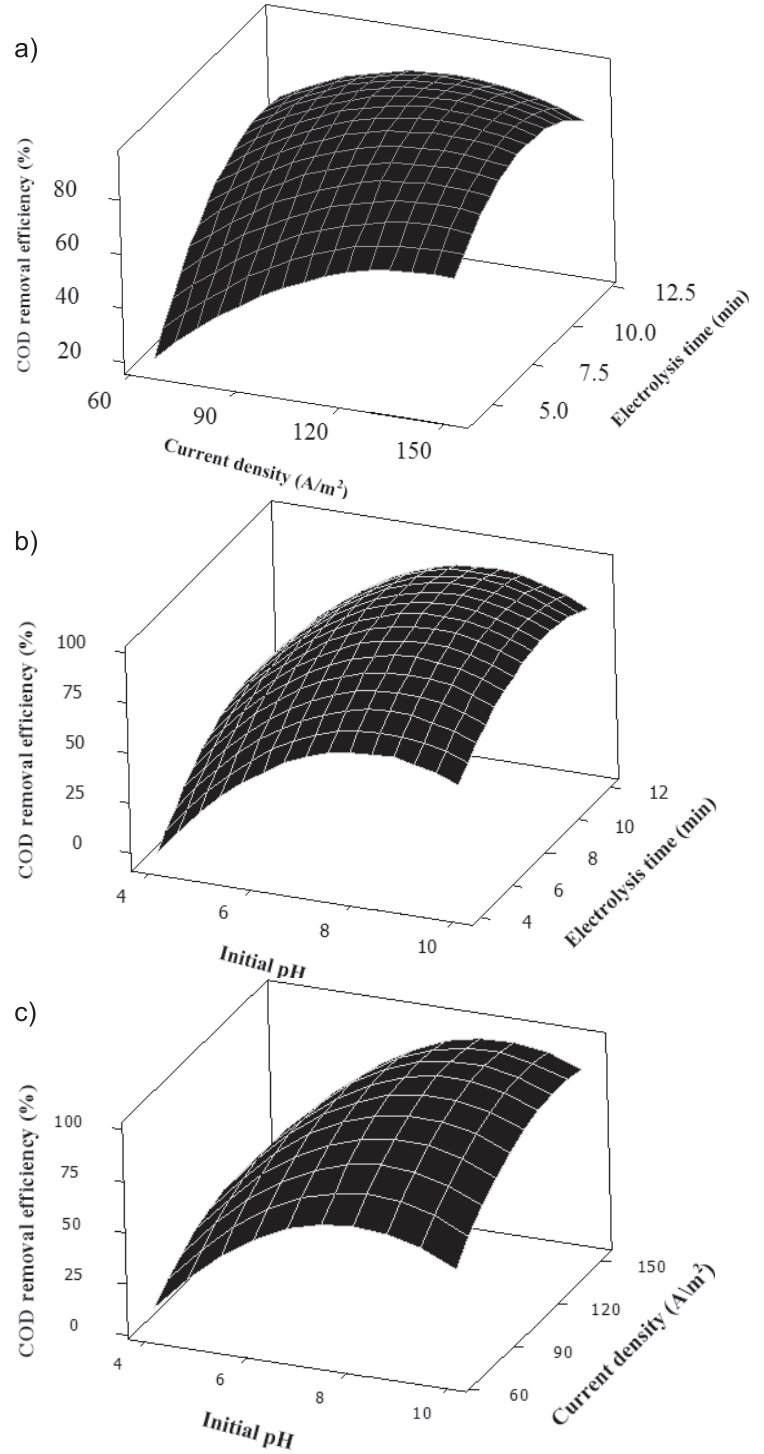

Fig. 2. Three-dimensional surfaces for COD removal efficiencies: a) current density vs. electrolysis time at $\mathrm{pH} 7$ ), b) initial $\mathrm{pH}$ vs. electrolysis time at current denisty $108.3 \mathrm{~A} / \mathrm{m}^{2}$, and c) initial $\mathrm{pH}$ vs.current density at electrolysis time $8 \mathrm{~min}$. may be due to the fact that the activities of coagulants (ferric iron ion) are suitable at slightly alkaline conditions as described in the research of BarreraDíaz and Palomar-Pardavé [22]. Fig. 2c) shows the combined effect of current density and initial $\mathrm{pH}$. It can be observed that COD removal efficiency increases together with the increasing of current density as initial pH slightly alkaline medium. Gengec and Kobya [23] suggested that with suitable $\mathrm{pH}$ range (neutral to slightly alkaline condition), the formed floc. had a large specific surface area that can absorb soluble organic compounds. Therefore, the maximum COD removal efficiency at high current density was achieved in relatively neutral medium.

\section{Optimizing the Treatment Process}

Optimum conditions are obtained by taking the top summit point of the response surface plots (Fig. 3). The EC process gives a maximum COD removal rate of $99.9 \%$ at an optimum initial $\mathrm{pH} 8.36$ and current density $126.2 \mathrm{~A} / \mathrm{m}^{2}$ during $9.7 \mathrm{~min}$ electrolysis. The predicted value is very close to the experimentally observed value of $97.3 \%$ (two additional tests at initial $\mathrm{pH} 8.5$, current density $130 \mathrm{~A} / \mathrm{m}^{2}$ during $9.5 \mathrm{~min}$ ). Increasing current density and electrolysis time beyond their optimal values might slightly decrease removal. This behaviour is due to the scavenging effect of iron coagulants, and the destabilisation of the iron (III) hydroxide flocs. appeared when excess iron ion was produced. These reasons could also contribute to the decrease in removal [23-24].

\section{Sludge Production and Operational Cost}

EC technology is widely known to be producing less sludge as compared with coagulation process. The production of EC is easily determined using Faraday's law:

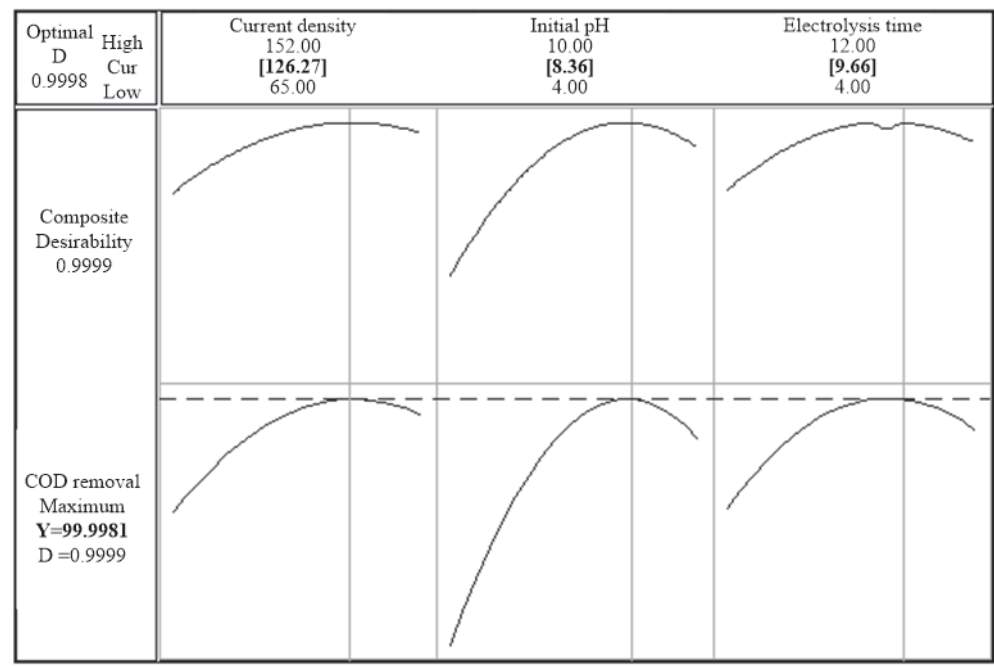

Fig. 3. Response optimization plot of maximum COD removal efficiency. 


$$
\mathrm{C}\left(\mathrm{g}_{\mathrm{Fe}} / \mathrm{m}^{3}\right)=\frac{\mathrm{ItM}}{\mathrm{ZFV}} \times 10^{3}
$$

...where $I$ is applied current (A), $t$ is the operating time (s), $M$ is the atomic weight of the iron $56(\mathrm{~g} / \mathrm{mol}), Z$ is the iron valance (in the case is 3 for $\mathrm{Fe}^{3+}$ ), $F$ is the Faraday constant $96485 \mathrm{C} / \mathrm{mol}$, and $V$ is the volume $(4 \mathrm{~L})$ of wastewater.

Electrical energy consumption and operational cost are important economical parameters in the EC process that were calculated by Equations (4) and (5), respectively:

$$
\begin{gathered}
\mathrm{E}_{\text {consumption }}\left(\mathrm{kWh} / \mathrm{m}^{3}\right)=\frac{\mathrm{UIt}}{3.6 \times 10^{3} \mathrm{~V}} \\
\text { Operation cost }=\alpha^{*} \mathrm{E}_{\text {consumption }}+\beta^{*} \mathrm{C}
\end{gathered}
$$

...where " $\alpha$ " and " $\beta$ " are electricity price 0.0492 \$US/ $\mathrm{KWh}$ and electrode material price $0.67 \mathrm{USD} / \mathrm{kg} \mathrm{Fe}\left(\mathrm{CT}_{3}\right)$, respectively (according to the Vietnam market in March 2017), and U represents cell voltage (V).

Based on the calculations, the energy consumption and theory cost are $7.13 \mathrm{kWh} / \mathrm{m}^{3}$ and $0.667 \$ / \mathrm{m}^{3}$, respectively, while the actual operating cost reaches $0.724 \$ / \mathrm{m}^{3}$ swine slaughterhouse wastewater at optimal conditions. Compared with other reports of iron EC for organic wastewater treatment [25-26], the actual operating cost for COD removal from the wastewater was economical effect. However, total material consumption was higher than theoretical value. Actual consumption of the dried electrodes was $0.210 \mathrm{~g} / \mathrm{L}$ at suitable EC process as compared with $0.165 \mathrm{~g} / \mathrm{L}$ of theoretical. These results could be accounted by the fact that practical production of $\mathrm{Fe}$ was influenced by Fe oxidation and wastewater characteristics such as: $\mathrm{pH}$, conductivity, and gas solubility as the state of Moussa and El-Naas [27].

\section{Conclusions}

The obtained results indicate that the EC process can be used for COD removal from swine slaughterhouse wastewater. The central composite design was successfully used to develop a mathematical model for predicting COD removal. The value of $\mathrm{R}^{2}=0.975$ for the obtained quadratic model indicates high correlation between observed and predicted values by the mathematical model. Optimization using RSM led to the optimum operating conditions as $130 \mathrm{~A} / \mathrm{m}^{2}$ current density, initial $\mathrm{pH} 8.5$, and 9.5 electrolysis time for the treatment of swine slaughterhouse wastewater, yielding COD removal with $97.3 \%$ efficiency. The actual operating cost and sludge production were $0.724 \$ / \mathrm{m}^{3}$ and $0.210 \mathrm{~g} / \mathrm{L}$ at the conditions.

\section{References}

1. NHAT P.H. Environmental performance improvement for small and medium-sized slaughterhouses in Vietnam. Environ. Dev. Sustain. 8 (2), 251, 2006.

2. IKEHATA K., JODEIRI NAGHASHKAR N., GAMAL EL-DIN M. Degradation of aqueous pharmaceuticals by ozonation and advanced oxidation processes: a review. Ozone. Sci. Eng. 28 (6), 353, 2006.

3. NACHEVA P., PANTOJA M., SERRANO E. Treatment of slaughterhouse wastewater in upflow anaerobic sludge blanket reactor. Water Sci. Technol. 63 (5), 878, 2011.

4. RAJAKUMAR R., MEENAMBAL T., BANU J.R., YEOM I.T. Treatment of poultry slaughterhouse wastewater in upflow anaerobic filter under low upflow velocity. Int. J. Environ. Sci. Technol. 8 (1), 149, 2011.

5. DEL POZO R., DIEZ V., SALAZAR G., ESPINOSA J.J. The influence of influent distribution and blood content of slaughterhouse wastewater on the performance of an anaerobic fixed-film reactor. J. Chem. Technol. Biotechnol. 81 (3), 282, 2006.

6. QIAO W., TAKAYANAGI K., SHOFIE M., NIU Q., YU H. Q., LI Y. Y. Thermophilic anaerobic digestion of coffee grounds with and without waste activated sludge as cosubstrate using a submerged AnMBR: System amendments and membrane performance. Bioresour. Technol. 150 (0), 249, 2013.

7. MILLAMENA O.M. Ozone treatment of slaughterhouse and laboratory wastewaters. Aquacult. Eng. 11 (1), 23, 1992.

8. WU J., DOAN H. Disinfection of recycled red-meatprocessing wastewater by ozone. J. Chem. Technol. Biotechnol. 80 (7), 828, 2005.

9. LUIZ D.B., GENENA A.K., JOSÉ H.J., MOREIRA R., SCHRÖDER H.F. Tertiary treatment of slaughterhouse effluent: degradation kinetics applying UV radiation or $\mathrm{H}_{2} \mathrm{O}_{2} / \mathrm{UV}$. Water Sci. Technol. 60 (7), 1869, 2009.

10. BUSTILLO-LECOMPTE C.F., GHAFOORI S., MEHRVAR M. Photochemical degradation of an actual slaughterhouse wastewater by continuous $\mathrm{UV} / \mathrm{H}_{2} \mathrm{O}_{2}$ photoreactor with recycle. J. Environ. Chem. Eng. 4 (1), 719, 2016.

11. HA M.B., XUYEN T.H.L. Removal of chemical oxygen demand from hospital wastewater using electrocoagulation. Mor. J. Chem. 5 (2), 371, 2017.

12. AITBARA A., CHERIFI M., HAZOURLI S., LECLERC J. P. Continuous treatment of industrial dairy effluent by electrocoagulation using aluminum electrodes. Desalin. Water Treat. 57 (8), 3395, 2016.

13. HA M.B. Modeling the removal of Sunfix Red S3B from aqueous solution by electrocoagulation process using artificial neural network. J. Serb. Chem. Soc. 81 (8), 959, 2016.

14. HA M.B., LOAN N.T.H., HAN C.T.L., KHUYEN T.N. The application of electro coagulation process for decolorization of reactive dyeing wastewater. Mor. J. Chem. 5 (2), 297, 2017.

15. ABDEL S.G.A., BARAKA A.M., OMRAN K.A., MOKHTAR M.M. Removal of Some Pesticides from the Simulated Waste Water by Electrocoagulation Method Using Iron Electrodes. Int. J. Electrochem. 7 (8), 6654, 2012. 
16. BENINCÁ C., VARGAS F.T., MARTINS M.L., GONÇALVES F.F., VARGAS R.P., FREIRE F.B., ZANOELO E.F. Removal of clomazone herbicide from a synthetic effluent by electrocoagulation. Water Sci. Technol. 73 (1), 2944, 2016.

17. MOLLAH M.Y.A., MORKOVSKY P., GOMES J.A.G., KESMEZ M., PARGA J., COCKE D.L. Fundamentals, present and future perspectives of electrocoagulation. J. Hazard. Mater. 114 (1-3), 199, 2004.

18. CLESCERL L.S., GREENBERG A.E., EATON A.D. Standard Methods for the Examination of Water and Wastewater, $20^{\text {th }}$ ed., American Public Health Association: Washington DC, United States, 1000, 1999.

19. ISA M.H. Simulated textile dye wastewater treatment by electrochemical oxidation: application of response surface methodology (RSM). Desalin. Water Treat. 53 (8), 2260, 2015.

20. MONTGOMERY D.C. Design and Analysis of Experiments. $8^{\text {th }}$ ed., John Wiley \& Sons: Massachusetts, United States, 478, 2012.

21. MAHTAB A., TARIQ M., SHAFIQ T., NASIR A. Coagulation/adsorption combined treatment of slaughterhouse wastewater. Desalin. Water Treat. 12 (1-3), 270, 2009.
22. BARRERA-DÍAZ C., PALOMAR-PARDAVÉ M., ROMERO-ROMO M., MARTINEZ S. Chemical and electrochemical considerations on the removal process of hexavalent chromium from aqueous media. J. Appl. Electrochem. 33 (1), 61, 2003.

23. GENGEC E., KOBYA M., DEMIRBAS E., AKYOL A., OKTOR K. Optimization of baker's yeast wastewater using response surface methodology by electrocoagulation. Desalination. 286 (0), 200, 2012.

24. AKYOL A. Treatment of paint manufacturing wastewater by electrocoagulation. Desalination. 285 (0), 91, 2012.

25. OZYONAR F., KARAGOZOGLU B. Operating cost analysis and treatment of domestic wastewater by electrocoagulation using aluminum electrodes. Pol. J. Environ. Stud. 20 (1), 173, 2011.

26. DANESHVAR N., OLADEGARAGOZE A., DJAFARZADEH N. Decolorization of basic dye solutions by electrocoagulation: An investigation of the effect of operational parameters. J. Hazard. Mater. 129 (1-3), 116, 2006.

27. MOUSSA D.T., EL-NAAS M.H., NASSER M., AL-MARRI M.J. A comprehensive review of electrocoagulation for water treatment: Potentials and challenges. J. Environ. Manage. 186, 24, 2017. 
